\title{
Farklı Kurutma Yöntemlerinin İzmir Tipi Tütün Çeşitlerinde Bazı Kimyasal Özellikleri ile Verim ve Tütün Kalitesine Etkileri
}

\author{
Sidıka Ekren ${ }^{1 *}$, Deniz Vural ${ }^{1}$ \\ ${ }^{1}$ Ege Üniversitesi Ziraat Fakültesi Tarla Bitkileri Bölümü Bornova/İzmir (ORCID: 0000-0002-6812-9586)
}

(İlk Geliş Tarihi 12 Eylül 2019 ve Kabul Tarihi 27 Ekim 2019)

(DOI: 10.31590 /ejosat.619270)

ATIF/REFERENCE: Ekren, S. \& Vural, D. (2019). Farklı Kurutma Yöntemlerinin İzmir Tipi Tütün Çeşitlerinde Bazı Kimyasal Özellikleri ile Verim ve Tütün Kalitesine Etkileri. Avrupa Bilim ve Teknoloji Dergisi, (17), 509-514.

\section{$\ddot{O} z$}

Bu çalışmanın amacı farklı kurutma yöntemlerinin İzmir tipi tütün çeşitlerinin bazı kimyasal özellikleri ile verim ve tütün kalitesine etkilerini belirlemektir. Araştırma 2018 yılında Denizli ili Acıpayam ilçesinde yürütülmüştür. Tesadüf blokları deneme desenine göre üç tekerrürlü olarak kurulmuştur. Çalışmada İzmir-Özbaş, Birlik-124, Birlik-128 ve Sarıbağlar-407 tütün çeşitleri ile geleneksel yöntem, vento makinası, elek usulü kurutma ve dizim makinası olmak üzere dört farklı tütün çeşidi ve kurutma yöntemi kullanılmıştır. Denemede toplam alkaloid (nikotin) (\%), toplam indirgen şeker (\%), ham kül (\%), verim ( $\left.\mathrm{kg} \mathrm{ha}^{-1}\right)$ tütün ekspertiz kalitesi gibi özellikler incelenmiştir. Araştırma sonuçlarına göre; nikotin, toplam indirgen şeker, ham kül ve verim değerleri sırasıyla \%0.55-1.27, \%8.59-15.39, \%17.6-27.8 ve 46-105 kg/da olarak bulunmuştur. En yüksek ekspertiz kalitesi geleneksel yöntemle kurutulan tütünlerden elde edilmiştir. Kurutma yöntemleri ve tütün çeşitleri bakımından en iyi sonuçlar Sarıbağlar-407 tütün tipinden ve geleneksel kurutma yönteminden saptanmıştır.

Anahtar Kelimeler: Tütün Tipi, Kurutma, Kimyasal Özellik, Verim ve Kalite

\section{The Effects of Different Curing Methods on Yield and Tobacco Quality With Some Chemical Components of Izmir Type Tobacco}

\begin{abstract}
The objective of this study was to determine the effects of different curing methods on yield and tobacco quality with some chemical components of Izmir type tobacco. This research was conducted in Acipayam, Denizli province in 2018. The experimental design was randomized complete block design with three replications. Four tobacco varieties and curing methods including Izmir-Ozbas, Birlik-124, Birlik-128, Saribaglar-407 and traditional, vento machine, curing on wire screen, mechanical stringing were used in this study. In the research, total alcaloid (nicotine) (\%), total reducing sugar (\%), crude ash (\%), yield $\left(\mathrm{kg}^{-1}\right)$ and tobacco expertise quality were determined. According to the results, nicotine, total reducing sugar, crude ash and yield were $0.55-1.27 \%, 8.59-15.39 \%$, 17.6-27.8\% and 46-105 $\mathrm{kg} \mathrm{ha}^{-1}$, respectively. The highest tobacco expertise quality were determined in traditional curing method. Better results were obtained in traditional curing methods at Saribaglar-407 tobacco varity in terms of curing methods and tobacco varieties.
\end{abstract}

Key Words: Tobacco Type, Curing, Chemical Properties, Yield and Quality

\footnotetext{
* Sorumlu Yazar: Ege Üniversitesi Ziraat Fakültesi Tarla Bitkileri Bölümü, İzmir, Türkiye, ORCHID: 0000-0002-6812-9586, sidika.ekren@ege.edu.tr
} 


\section{Giriș}

Tütün, keyf verici özelliğinden dolayı çok eski zamanlardan bu yana insanlar tarafından kullanılan bir bitkidir. Bu özelliği ile diğer tarla bitkilerine göre fark yaratmış ve günümüze kadar artan bir değer kazanmıştır. Fide yetiştirmesi, kırımı, kurutulması ve işlenmesi ile de başlı başına özellikleri olan bir endüstri bitkisidir.

Türk tarımının geleneksel ihraç ürünleri arasında yer alan bu bitkinin ülkemiz açısından ekonomik öneminin yanı sıra geniş bir üretici kesiminin de gelir kaynağını oluşturması yönüyle de değeri fazladır. Ülkemizde üretilen tütünlerin hemen hemen tamamını oriental tipi tütünler oluşturmaktadır. 2017 yılı itibariyle ülkemizde üretilen tütünün \% 60.5’i Ege, \% 15.8'i Güneydoğu, \% 11.9’u Karadeniz, \% 2.6'sı Marmara, \% 2.5'i Akdeniz ve \% 6.6's1 Doğu Anadolu Bölgemizde üretilmektedir. \% 60.5'lik pay ile ilk sirada yer alan bölgemizin 2017 yılı üretim miktarı 44.918 kilodur. Üretimde birinciliği koruyan Ege Bölgesi, dış satım bakımından da önemli bir yere sahiptir ve 2017 yılında ihracatı yapılan tütünlerin \% 78.8'i bu bölgeden karşılanmıştır (Anonim, 2018).

Ülke ekonomisi açısından önemli olan bu bitkinin yıldan yıla ciddi boyutta bir azalışı söz konusudur. Bu azalışın temel nedenlerinin başında üreticiye ödenen birim fiyatın yetersizliği gelmektedir. Yoğun bir emek ve iş gücü isteyen tütün tarımının tohumundan hasatına, hasatından işlenmesine kadar her evresinin iyi bilinmesi gerekir. Bu evrelerdeki işlemlerden en önemli olanı ise kurutmadır. Tütünlerin el el hasat edilmesi ve hasat edilmiş tütün yapraklarının dizim maliyetlerinin de birim fiyata göre yüksek olması üretici için ekonomik anlamda önemli bir dar boğaz olarak görülmektedir.

Oriental tütünler genellikle, güneşte veya plastik örtülü tünellerde kurutulmaktadır. Ancak son yıllarda üretim maliyetlerini tütün kalitesini düşürmeden farklı kurutma yöntemleri geliştirilmektedir. Geleneksel kurutma yöntemine alternatif olarak file usulü ile kurutma sistemi ve elekte kurutma yöntemleri gibi metotlar da kullanılmaya başlanmıştır. Hasat sonrası işçiliğin azaltılmasını amaçlayan bu yöntemler Orta Karadeniz, Doğu ve Güneydoğu Anadolu ve araştırma tarlamızın da içinde bulunduğu Ege Bölgesi’nde belirli üretim merkezlerinde, firmaların öngördügü çiftçiler ile yapılmaktadır.

Çalışmamızda, Ege Bölgesi tütüncülüğünde önemli üretim merkezlerinden olan Tavas yöresinde, farklı kurutma yöntemlerinin İzmir tipi tütün çeşitlerinde, bazı kimyasal özellikler ile verim ve ekspertiz kalitesi üzerine etkisinin araştırılması amaçlanmıştır.

\section{Materyal ve Yöntem}

Çalışma 2018 yılı tütün üretim sezonunda Denizli ili Acıpayam ilçesinde yürütülmüştür. Tesadüf blokları deneme deseni’ne göre 3 tekerrürlü olarak yürütülen araştırmada İzmir-Özbaş, Birlik-124, Birlik-128 ve Sarıbağlar-407 tütün çeşitleri deneme materyali olarak kullanılmıştır. Tablo 1'de kullanılan çeşitlerin bazı genel özellikleri gösterilmiştir.

Tablo 1. Denemede Kullanılan Tütün Çeşitlerinin Bazı Özellikleri

\begin{tabular}{|l|l|l|l|l|}
\hline & İzmir Özbas & Birlik 124 & Birlik 128 & Sarıbağlar 407 \\
\cline { 2 - 5 } Toprak isteği & Kır taban, Tınlı kumlu & $\begin{array}{l}\text { Hafif eğimli, } \\
\text { Kır - Kır taban }\end{array}$ & $\begin{array}{l}\text { Hafif eğimli, } \\
\text { Kır - Kır taban }\end{array}$ & Hafif eğimli \\
\hline $\begin{array}{l}\text { Bitki boyu } \\
\text { (cm) }\end{array}$ & Orta ya da uzun boylu & Orta boylu & Orta boylu & Orta boylu \\
\hline $\begin{array}{l}\text { Yaprak saylsı } \\
\text { (adet/bitki) }\end{array}$ & $26-48$ & $41-44$ & $40-42$ & $30-45$ \\
\hline Yetiştirme özellikleri & $\begin{array}{l}\text { Kuraklığa ve mavi küfe } \\
\text { dayanılı }\end{array}$ & Kuraklığa dayanıklı & Kuraklığa dayanıklı & $\begin{array}{l}\text { Kuraklığa dayanıklı, } \\
\text { mavi küfe karşı hassas }\end{array}$ \\
\hline Verim $($ kg/da $)$ & $80-150$ & $90-150$ & $80-130$ & $80-120$ \\
\hline
\end{tabular}

Tütün tohumları çok kü̧̧ük olduğu için fidelikte pişkin fide haline gelinceye kadar yetiştirilip sonra tarlaya dikilmiştir. Tohumların fideliğe ekimi Şubat ayında $\mathrm{m}^{2}$ ye $0.6 \mathrm{~g}$ tohum gelecek şekilde fidelik harcına ekilmiştir. Fidelerin yetişme döneminde fidelikte havalandırma, sulama, yabancı ot temizliği gibi kültürel işlemler fidelerin ihtiyacına ve ortam koşullarına göre düzenli aralıklarla yapılmıştır. Tarla fidelerin dikiminden önce sonbaharda derin ilkbaharda dikimden 1 ay önce ise normal sürüm yapılmış ve tırmık çekilmiştir. Dikim öncesi dekara $10 \mathrm{~kg}$ 15:15:15 kompoze gübresi uygulanmıştır. Pişkin hale gelen fideler fidelikten elle sökülerek tarlaya Nisan-Mayıs aylarında tütün dikim makinası ile 40x10 cm dikim normunda dikilmiştir. Dikim sonrası fidelere can suyu verilmiştir. $2 \mathrm{kez}$ çapalama yapılan bitkiler hasat olgunluğuna gelince elle kırılarak hasat işlemi gerçekleştirilmiştir. 3 elde tamamlanan hasat Temmuz-Ağustos aylarında yapılmıştır. Kırımı yapılan tütün yaprakları 4 farklı şekilde kurutulmuştur.

1. Geleneksel yöntemle kurutma

2. Elek usulü yöntemle kurutma

3. Dizim makinası ile dizilmiş tütünlerin kurutulması

4. File makinası (vento) yöntemiyle kurutma

1.Geleneksel Yöntemle Kurutma: Ege Bölgesi tütünlerinde kullanılan bir yöntemdir. Izgarada kurutma da denilmektedir. Kargılar birbirleriyle temas etmeyecek ve hava alacak şekilde ızgaraya yerden $60-80 \mathrm{~cm}$ yükseklikte yerleştirilir. Yaprak ayasının kuruması 
ortam şartlarına ve el grubuna değişmekle birlikte 4-8 gün arasında sürmektedir. Daha sonra yaprak damarının kuruması için kargılar yere serilir. 4-6 gün süresince damar kuruması tamamlanır ve tütünler istife alınır.

2.Elek usulü yöntemle kurutma: İşçilik maliyetlerini azaltmak için son yıllarda kullanılan bir yöntemdir. Etrafına çıta çatılmış paslanmaz bir tel üzerine tütünler pastal sıralar halinde serilir. Ortam sıcaklığına göre tütünlerin kurutulması 7-12 günde tamamlanmaktadır.

3.Dizim makinası ile dizilmiş tütünlerin kurutulması: Kırımı yapılan tütün yaprakları boyutlarına göre her göze eşit miktarda gelecek şekilde dizim makinasının içerisinde bulunan kasetlere yerleştirilir. İğnelere ipler geçirilerek kırılan yapraklar önce iğneye oradan da ipe geçirilerek kurutmaya bırakılır.

4.File makinası (vento) yöntemiyle kurutma: Kırılan tütün yaprakları daha önceden istenen boyutlarda hazırlanmış olan filelere doldurulmak adına, makinenin besleme ünitesine doldurulur. Besleme ünitesinden homojen bir şekilde vakum ünitesine gönderilen tütün yaprakları vakum yardımı ile filelere aktarılır. File, istenen dolum ağılıklarına ulaştı̆ında makine durdurularak file ağızları bağlanır. Ardından boy ve kilo ölçümleri gerçekleştirilir. Dolumu tamamlanan filelerin yatay veya dikey olarak kurutulması söz konusu olup yerde kurutulma yapılmamalıdır. Bunun sebebi ise yerde kurutmada alttan ve üstten hava akışı olmamakta ve tütün yaprakları kararmaktadır. Soldurma süresi, el gruplarına göre değişmekle beraber 24-48 saat, kurutma süresi ise 10-15 gün sürmektedir. Yaprakları tamamen kurumuş olan fileler istiflenip, tavlanmıştır (Anonim, 2012).

Her bir yönteme göre ayrı ayrı kurutulan tütünlerden 1'er kg'lık örnek tesadüfi olarak alınmış ve toplam alkaloid (nikotin) (\%) (Anonim, 1969), toplam indirgen şeker (\%) (Lindsay, 1973), ham kül (\%) (Nelson, 1960), verim (kg/da) ve ekspertiz değerlendirmesi (randıman) (Anonim, 2006) gibi özellikler incelenmiştir. Verilerin istatistiki değerlendirmesi Tesadüf Blokları Deneme Deseni’ne göre 3 tekerrürlü olarak Totem Stat programında yapılmıştır (Açıkgöz ve ark., 2004).

\section{Araştırma Sonuçları ve Tartışma \\ 3.1. Toplam İndirgen Şeker (\%)}

Toplam indirgen şeker oranına ilişkin elde ettiğimiz rakamlara uygulanan istatistiki analiz sonucunda kurutma yönteminin, tütün çeşitlerinin ve kurutma yöntemi*tütün çeşitleri interaksiyonlarının istatistiksel açıdan önemli oldukları Tablo 2'de görülmektedir. En yüksek şeker içeriği \%16.66 ile Sarıbağlar-407 çeşidinin geleneksel yöntem ile kurutmasından elde edilmiş̧ir. En düşük şeker oranı ise Birlik 124 çeşidinin dizim makinası (\%8.59) ile kurutulmasında bulunmuştur. Çeşitler ve kurutma yöntemleri açısından en yüksek şeker miktarları, \%13.59 ile Sarıbağlar-407 çeşidi ve \%13.70 ile geleneksel yöntem; en düşük ise \%10.53 ile Birlik-128 çeşidi ve \% 9.94 şeker oranı ile dizim makinası ile kurutulan tütünlerde tespit edilmiştir. Tütünde şeker miktarının belirli bir düzeye kadar olmasının istendiğini ve düşük şeker içeriği kadar yüksek şekerin de kaliteyi olumsuz etkilediğini tespit edilmiştir (Tso, 1972). Çalışmamızda bulduğumuz şeker içerikleri \% 8.59-16.66 arasında değişmiştir.

Ege tütünlerinin şeker içeriklerinin yüksek olması ürünün kaliteli olduğu anlamına gelmekte olup bu durum sınırlı bir çerçevede kabul edilmektedir. Çünkü tütün mamulü harmanlarında protein oranı ve onların karbonhidratlara göre katsayısı çok önemlidir. Karbonhidratların diğer maddelerle olan dengesi içim kalitesini ortaya koyan önemli bir kalite öğesidir. İzmir menşei tütünlerde şeker içeriği \%8-10'dan düşük ise istenilen kalite kriterleri bakımından yetersiz olarak değerlendirilmektedir. (Mercimek, 2016). Yaprak tütün örneklerinde şeker miktarları onların ekspertiz kalitesi üzerine de etkili olmaktadır. Randıman oranı yüksek olan tütünlerin şeker miktarları da makul oranda yüksektir. Düşük kaliteli tütünlere doğru şeker içerikleri azalmaktadır (Sekin, 1979). Araştırmamızda elde ettiğimiz verilere benzer rakamlar Sekin ve Peksüslü, (1995), Ekren (2007) ve Çelen ve ark., (2015) ile uyumlu olduğu görülmektedir.

Tablo 2. Farklı Kurutma Yöntemi ile Kurutulan Tütün Çeşitlerinin Toplam İndirgen Şeker içerikleri (\%)

\begin{tabular}{|l|l|l|l|l|l|}
\hline Kurutma/Çeşit & Vento & Elek & $\begin{array}{l}\text { Dizim } \\
\text { Makinası }\end{array}$ & Geleneksel & Ortalama \\
\hline Birlik 124 & $9,47^{\mathrm{b}}$ & $14,30^{\mathrm{a}}$ & $8,59^{\mathrm{b}}$ & $10,31^{\mathrm{b}}$ & $10,67^{\mathrm{b}}$ \\
\hline Birlik 128 & $11,30^{\mathrm{a}}$ & $9,33^{\mathrm{a}}$ & $9,06^{\mathrm{a}}$ & $12,44^{\mathrm{a}}$ & $10,53^{\mathrm{b}}$ \\
\hline İmir Özbaş & $11,90^{\mathrm{bc}}$ & $16,17^{\mathrm{a}}$ & $10,43^{\mathrm{c}}$ & $15,39^{\mathrm{ab}}$ & $13,47^{\mathrm{a}}$ \\
\hline Sarıăğlar 407 & $14,50^{\mathrm{ab}}$ & $11,49^{\mathrm{b}}$ & $11,69^{\mathrm{b}}$ & $16,66^{\mathrm{a}}$ & $13,59^{\mathrm{a}}$ \\
\hline Ortalama & $11,79^{\mathrm{b}}$ & $12,82^{\mathrm{ab}}$ & $9,94^{\mathrm{c}}$ & $13,70^{\mathrm{a}}$ & 12,07 \\
\hline
\end{tabular}

$\mathrm{p}<0.05 \operatorname{LSD}_{\mathrm{C}} 1.827 * * \quad \mathrm{p}<0.05 \operatorname{LSD}_{\mathrm{k}} 1.827 * * \mathrm{p}<0.01 \mathrm{LSD}_{\text {CХXK }} 3.654 *$ 


\subsection{Toplam Alkaloid (Nikotin) (\%)}

Toplam alkaloid oranlarına ilişkin veriler Tablo 3'de verilmiştir. Kurutma yöntemlerine göre değişimler $p<0.05$, tütün çeşitlerine göre $\mathrm{p}<0.01$ düzeyinde önemli bulunurken, aralarındaki interaksiyonun önemsiz olduğu belirlenmiştir. Tablo 3'de nikotin içerikleri \%0.36-1.27 arasında değiştiği saptanmıştır. Kurutma yöntemleri bakımından nikotin oranlarına ilişkin değerler incelendiğinde en yüksek nikotinin \%1.19 ile dizim makinasından, en düşük ise \%0.62 ile elek usulü kurutma yönteminden elde edilmiştir. Çeşitler açısından ise Birlik124 çeşidi \%1.05 ile en yüksek nikotin içeriğine sahip olurken, \%0.78 ile Sarıbağlar-407'de en düşük nikotin oranını tespit edilmiştir.

Çalışmamızda kurutma yöntemleri açısından nikotin miktarı en yüksek dizim makinasında bulunmuş onu sırasıyla geleneksel, vento ve elek usulü yöntemler izlemiştir. Elek ve filede kurutulan tütünler dizim yapılmadan gelişigüzel elek üzerine serilmiş ve fille içerisine doldurulmuştur. Yapraklarda su kaybı dizim makinası ve geleneksel yöntemde daha hızlı ve daha fazla olmuştur. Tütünün kimyasal kompozisyonu (nikotin, şeker vb) yetiştirildiği yörenin iklim, toprak özellikleri, uygulanan kültürel işlemler, hasat zamanı ve kurutma işlemlerine göre farklılıklar göstermektedir. Sigara harmanlarında nikotin miktarının yüksek olması içim kalitesi açısından etkilemektedir. Boğazda sertlik, acılık gibi fizyolojik etkiler yaratmaktadır. İçim kalitesi açısından büyük önem taşıyan nikotin miktarı Ege Bölgesi tütünlerinde \% 0.51-0.85 oranlarında olduğunu bildirmişlerdir (Peksüslü ve Gencer, 2001).

Kırımı yapılmış tütün yapraklarında, soldurma ve sarartma aşamasından 3-5 gün sonra yaprağın canlılığ $\% 50$ oranında devam etmektedir. Nişastanın hidrolize olması ve hasattan 7-8 gün sonra \%3-4 oranında bulunması hızlı bir şekilde şekere dönüşmesi ile gerçekleşmektedir. Bu aşamada azotun da belirgin bir şekilde aminoasitlere parçalanması söz konusu olmaktadır (Wolf, 1962).

Ege Bölgesi için nikotin miktarının \%1 civarında olması istenmektedir. Yapılan çalışmalarda nikotin içeriği \%0.25-1.90 arasında değişen sonuçlar verdiği belirlenmiştir (Uz, 1997; Ekren, 2007; Çelen ve ark., 2015). Araştırmamızda bulduğumuz sonuçlar belirtilen nikotin aralıkları arasında değiştiği tespit edilmiştir.

Tablo 3. Farklı Kurutma Yöntemi ile Kurutulan Tütün Çeşitlerinin Toplam Alkaloid (Nikotin) Içerikleri (\%)

\begin{tabular}{|c|c|c|c|c|c|}
\hline Kurutma/Çeşit & Vento & Elek & $\begin{array}{l}\text { Dizim } \\
\text { Makinası }\end{array}$ & Geleneksel & Ortalama \\
\hline Birlik 124 & 0,86 & 0,87 & 1,19 & 1,27 & $1,05^{\mathrm{a}}$ \\
\hline Birlik 128 & 0,68 & 0,61 & 1,22 & 1,11 & $0,91^{\mathrm{ab}}$ \\
\hline İzmir Özbaş & 1,07 & 0,36 & 1,27 & 0,81 & $0,88^{\mathrm{ab}}$ \\
\hline Sarıbağlar 407 & 0,55 & 0,65 & 1,09 & 0,83 & $0,78^{b}$ \\
\hline Ortalama & $0,79^{c}$ & $0,62^{\mathrm{c}}$ & $1,19^{\mathrm{a}}$ & $1,01^{\mathrm{b}}$ & 0,90 \\
\hline
\end{tabular}

$$
\mathrm{p}<0.01 \operatorname{LSD}_{\mathrm{C}} 0.185^{* *} \quad \mathrm{p}<0.05 \operatorname{LSD}_{\mathrm{K}} 0.185 * \operatorname{LSD}_{\mathrm{C} X \mathrm{KK}} \mathrm{ns}
$$

\subsection{Ham Kül (\%)}

Ham kül oranına ilişkin verilere uygulanan istatistiki değerlendirme sonucunda kurutma yöntemleri, çeşitler ve bunlar arasındaki interaksiyon önemsiz bulunmuştur (Tablo 4). Rakamsal arası farklılık söz konusudur. Elde edilen ham kül oranları \%17.6-27.8 arasında değişim göstermiştir. En yüksek ham kül \%24.8 ile Birlik-128 tütün çeşidinde, \%24 kül içeriğiyle elek usulü kurutma yönteminde saptanmıştır.

Kül oranı tütün kalitesini belirleyen önemli bir faktördür. Yaprakta kül içeriği ile yaprak tütün kalitesi arasında ters bir orantı olduğu saptanmıştır (Sekin, 1979). Ege Bölgesi’nin değişik yörelerinden alınan tütün örneklerinde yapılan ham kül değerleri \%11.2625.07 arasında belirlenmiştir (Tuncay ve ark., 1985; Uz, 1997; Gencer, 2001; Ekren, 2007 ve Mercimek, 2016). Araştırmada bulduğumuz bu değerler yukarıda adı geçen literatür bilgileriyle uyumlu olduğu görülmektedir.

Tablo 4. Farklı Kurutma Yöntemi ile Kurutulan Tütün Çeşitlerinin Ham Kül Iç̧erikleri (\%)

\begin{tabular}{|l|l|l|l|l|l|}
\hline Kurutma/Çeşit & Vento & Elek & $\begin{array}{l}\text { Dizim } \\
\text { Makinası }\end{array}$ & Geleneksel & Ortalama \\
\hline Birlik 124 & 23,3 & 22,5 & 23,4 & 24,3 & 23,4 \\
\hline Birlik 128 & 26,0 & 24,9 & 22,9 & 25,4 & 24,8 \\
\hline İmir Özbaş & 23,3 & 20,8 & 24,1 & 22,2 & 22,6 \\
\hline Sarıbăglar 407 & 21,1 & 27,8 & 21,4 & 17,6 & 22,0 \\
\hline Ortalama & 23,4 & 24,0 & 23,0 & 22,6 & 23,2 \\
\hline
\end{tabular}

$$
\operatorname{LSD}_{\mathrm{C}} \mathrm{ns} \quad \mathrm{LSD}_{\mathrm{K}} \mathrm{ns} \quad \mathrm{LSD}_{\mathrm{C} \mathrm{XX}} \mathrm{ns}
$$




\subsection{Verim $(\mathrm{kg} / \mathrm{da})$}

Tablo 5 incelendiğinde, çeşit ve çeşit*kurutma yöntemi arasındaki interaksiyon \%1, kurutma yöntemleri arasındaki fark ise \%5 düzeyinde önemli bulunmuştur. En düşük verim değeri $46 \mathrm{~kg} / \mathrm{da}$ ile Birlik-128 çeşidinin geleneksel yöntem ile kurutulmasından elde edilmiştir. Verim miktarı en yüksek $105 \mathrm{~kg} / \mathrm{da}$ ile geleneksel yöntemde Sarıbağlar-407 tütün çeşidinde bulunmuştur. Verim değerleri 46-105 kg/da arasında değiştiği saptanmıştır.

Kurutma yöntemleri açısından sonuçlar yorumlandığında, en yüksek verim $81.8 \mathrm{~kg} / \mathrm{da}$ ile geleneksel yöntemde bulunmuştur. Onu sırasıyla dizim makinası, vento ve elek usulü kurutma yöntemleri izlemiştir. Aynı çizelgede çeşit ortalamaları değerlendirildiğinde, $86.8 \mathrm{~kg} / \mathrm{da}$ ile İzmir-Özbaş ve Sarıbağlar-407 tütün çeşitlerinde verim miktarı Birlik-124 ve Birlik-128 çeşitlerine göre daha yüksek tespit edilmiştir. En düşük verim $63 \mathrm{~kg} / \mathrm{da}$ ile Birlik-128 tütün çeşidinde bulunmuştur.

Kurutma yöntemi ve süresinin verim miktarı üzerine etki edebileceği, güneşte kurutma yöntemi ile kurutulan tütünlerin daha fazla ağırlık kaybına maruz kaldıkları, kurutma gün sayısı arttıkça kuru madde kaybının da arttığı, tütün yaprağının kimyasal içeriğinin de kurutma süresine bağlı olarak değiştiği belirtilmektedir (Özçam ve Sekin, 1983; Sekin, 1987; Yazan ve ark., 1993). Kuru yaprak tütün veriminin Ege Bölgesi tütünlerinde 80-250 kg/da arasında değiştiği görülmüştür (Otan ve ark., 1989; Er, 1994; Uz, 1997, Ekren, 2007). Araştırmamızda elde ettiğimiz bazı verim değerlerinin yukarıda belirtilen verim aralığının altında bulunmuştur. Bu durumun kullanılan tütün çeşidi ve kurutma yönteminden kaynaklandığı düşünülmektedir.

\section{Tablo 5. Farklı Kurutma Yöntemi ile Kurutulan Tütün Çeşitlerinin Verim Içerikleri $(\mathrm{kg} / \mathrm{da})$}

\begin{tabular}{|l|l|l|l|l|l|}
\hline Kurutma/Çeşit & Vento & Elek & $\begin{array}{l}\text { Dizim } \\
\text { Makinası }\end{array}$ & Geleneksel & Ortalama \\
\hline Birlik 124 & $79,3^{\mathrm{b}}$ & $65,0^{\mathrm{c}}$ & $52,0^{\mathrm{d}}$ & $85,0^{\mathrm{a}}$ & $70,3^{\mathrm{b}}$ \\
\hline Birlik 128 & $73,0^{\mathrm{a}}$ & $62,0^{\mathrm{c}}$ & $71,0^{\mathrm{b}}$ & $46,0^{\mathrm{d}}$ & $63,0^{\mathrm{c}}$ \\
\hline$\dot{I}_{z}$ ir Özbaş & $88,0^{\mathrm{c}}$ & $79,0^{\mathrm{d}}$ & $89,0^{\mathrm{b}}$ & $91,0^{\mathrm{a}}$ & $86,8^{\mathrm{a}}$ \\
\hline Sarıağlar 407 & $64,0^{\mathrm{d}}$ & $81,0^{\mathrm{c}}$ & $97,0^{\mathrm{b}}$ & $105,0^{\mathrm{a}}$ & $86,8^{\mathrm{a}}$ \\
\hline Ortalama & $76,1^{\mathrm{d}}$ & $71,8^{\mathrm{c}}$ & $77,3^{\mathrm{b}}$ & $81,8^{\mathrm{a}}$ & 76,8 \\
\hline \\
p<0.01 LSD \\
\hline
\end{tabular}

\subsection{Ekspertiz Değerlendirmesi (Randıman)}

Ekspertiz değerlendirmesi üzerine çeşit, kurutma yöntemi ve çeşit*kurutma yöntemi arasındaki interaksiyonun p \%1 düzeyinde önemli olduğu Tablo 6'da belirtilmiştir. Randıman değerleri 56-70 arasında belirlenmiştir. En düşük verim Birlik-128 tütün çeşidinin dizim makinası ile dizilerek kurutulmasından elde edilen tütünlerde tespit edilmiştir. En yüksek verim ise istatistiki değerlendirme sonucunda aynı grup içerisinde yer alan geleneksel yöntemde kurutulan Sarıbağlar-407 ve İzmir-Özbaş tütün çeşitlerinden elde edilmiş olup sırasıyla 70 ve 69 randıman olarak bulunmuştur.

Kurutma yöntemleri bakımından çizelge incelendiğinde, en iyi randıman geleneksel yöntem ile kurutulan tütünlerde (65 randıman) en düşük ise dizim makinası ile kurutulan tütünlerde (60 randıman) olarak tespit edilmiştir. Vento ve elek usulü yöntemde kurutulan tütünlerin ise randıman miktarı 62 randıman olarak aynı değerde saptanmıştır. Çeşitler açısından ekspertiz değerlendirmesi 57-66 randıman arasında elde edilmiştir. En yüksek İzmir-Özbaş tütününde belirlenmiş onu sırasıyla Sarıbağlar-407, Birlik-124 ve Birlik-128 tütünleri izlemiştir.

Tütün çevre koşullarından, toprak yapısından uygulanan kültürel işlemlerden ve kurutma yöntemlerinden çok etkilenen bir bitkidir. Geleneksel ve file usulü kurutma yöntemleriyle kurutulan İzmir tütününde, file usulü kurutma yönteminde AG (Amerikan Grad) oranı \%42.0; KP (Kapa Grad) ise \%22.0; geleneksel kurutma yönteminde ise AG miktar1 \%32.4, Kapa ise \%25.2 olarak belirlemişlerdir (Çelen ve ark. 2015).

Çalışmamızda en iyi randıman miktarının geleneksel yöntemle kurutulan tütünlerden elde edildiği sonucuna varılmış ve bu sonucun yöntemi çiftçilerin uzun yıllardan bu yana kullanıyor olmasından kaynaklandığı düşünülmektedir. Vento ve elek usulü yönteme üreticiler yeni yeni geçiş yaptıkları bilinmektedir. Dizim makinası ile dizilerek kurutulan tütünler ise daha çok Karadeniz Bölgesi tütünlerinde uygulanmakta olup Ege Bölgesi tütünlerinde hemen hemen hiç kullanılan bir yöntem olmadığı bilinmektedir. 
Tablo 6. Farklı Kurutma Yöntemi ile Kurutulan Tütün Çeşitlerinin Ekspertiz Değerlendirmesi

\begin{tabular}{|l|l|l|l|l|l|}
\hline Kurutma/Çeşit & Vento & Elek & $\begin{array}{l}\text { Dizim } \\
\text { Makinası }\end{array}$ & Geleneksel & Ortalama \\
\hline Birlik 124 & $61^{\mathrm{c}}$ & $64^{\mathrm{a}}$ & $61^{\mathrm{b}}$ & $61^{\mathrm{b}}$ & $62^{\mathrm{c}}$ \\
\hline Birlik 128 & $66^{\mathrm{c}}$ & $59^{\mathrm{a}}$ & $56^{\mathrm{c}}$ & $58^{\mathrm{b}}$ & $57^{\mathrm{d}}$ \\
\hline İmir Özbaş & $65^{\mathrm{c}}$ & $68^{\mathrm{b}}$ & $60^{\mathrm{d}}$ & $69^{\mathrm{a}}$ & $66^{\mathrm{a}}$ \\
\hline Sarıağlar 407 & $68^{\mathrm{b}}$ & $57^{\mathrm{d}}$ & $63^{\mathrm{c}}$ & $70^{\mathrm{a}}$ & $65^{\mathrm{b}}$ \\
\hline Ortalama & $62^{\mathrm{b}}$ & $62^{\mathrm{b}}$ & $60^{\mathrm{c}}$ & $65^{\mathrm{a}}$ & 62 \\
\hline
\end{tabular}

$p<0.01 \mathrm{LSD}_{\mathrm{C}} 0.120^{* *} \quad \mathrm{p}<0.01 \mathrm{LSD}_{\mathrm{K}} 0.120^{* *} \quad \mathrm{p}<0.01 \mathrm{LSD}_{\mathrm{CXK}} 0.241 * *$

\section{Sonuç}

> Çalı̧̧mamızda incelediğimiz kimyasal özelliklere ilişkin sonuçlar Ege Bölgesi tütünleri için istenilen değerler arasındadır.

> Verim miktarı Birlik-124 çeşidi hariç diğer tütün çeşitleri için bölge ortalamasına yakın değerdedir.

$>$ Randıman miktarları açısından yorumlandığında ise orta düzeydedir.

> Kurutma tipleri bakımından verim dâhil tüm özelliklerde GELENEKSEL KURUTMA yöntemiyle SARIBAĞLAR 407 çeşidi en iyi sonucu vermiştir.

> Maliyet ve işgücü yönünden bakıldığında ise VENTO MAKİNASI en kârlı kurutma yöntemidir.

\section{Kaynakça}

Açıkgöz. N., İlker, E., Gökçöl, A., 2004, Biyolojik araştırmaların Bilgisayarda Değerlendirilmeleri E.Ü. Tohum Teknoloji Uygulama ve Araştırma Merkezi Yayın No:2 Bornova/İzmir.

Anonim, 1969, Bestimmung Der Alkaloide in Tabakerzeugnissen. Deutschenormen. DK.663. 57. 543.062. 547. 94 DIN 1024.

Anonim, 2006. TSE 1000 Türk Tütünleri Standardı UDK 633.71. Ankara.

Anonim, 2012. İzmir Tütünü Yetiştirme Tekniği. Ege İhracatçı Birlikleri. İzmir.

Anonim, 2018. Tütün Raporu. Tütün Eksperleri Derneği. İzmir.

Çelen, A.E., Yuksel, O., Ekren, S. ve İlker, E., 2015. The Effects of Different Curing Methods on Some Chemical Properties and Tobacco Quality of Izmir Type Tobacco. 26th International Scientific Expert Conference of Agriculture and Food Industry. 27-30 September 2015. Sarejova/Bosna-Herzogania. (Oral Presentation)

Ekren, S., 2007, Ege Bölgesi Tütünlerinde Verim ve Kalitenin Değişmesinde Etken Olan Faktörlerin Araştırılması. E.Ü. Fen Bilimleri Enstitüsü. Doktora Tezi. Bornova-İzmir.

Er, C., 1994. Tütün. İlaç ve Baharat Bitkileri. A.Ü.Z.F. Yayınları. Yayın No: 1359. Ankara.

Gencer, S., 2001. Türkiye Tütün Çeşitleri. Ege Tarımsal Araştırma Enstitüsü Yayınları. Yayın No: 101. Menemen / İzmir.

Lindsay, H., 1973, A Clorimetric Estimation of Reducing Sugars in Potatoes. Potato Res. 16: 176-179.

Mercimek, V.H., 2016. Oriental Tütünde (Nicotiana tabacum L.) Hasat Sonrası Farklı Kurutma Sistemlerinin Verim ve Kalite Özelliklerine Etkileri. Gaziosmanpaşa Üniversitesi Fen bilimleri Enstitüsü. Tarla Bitkileri Anabilim Dalı. Tokat.

Nelson, R.A., 1960, Potantiometric Determination of the Chloride Content of Tobacco. Journal of the A.O.C 43. 3518.

Otan, H., Apti, R., 1989. Tütün. T.C. T.O.K.İ.B. Ege Tarımsal Araştırma Enstitüsü Yayınları No: 83. Menemen-İzmir.

Özçam, A., Sekin, S., 1983. Ege Bölgesinde Uygulanan Değişik Kırım Zamanı ve Kurutma İşlemlerinin Ege 64 Tütününün Kalitesinde Meydana Getirdiği Değişmeler. Tekel Enstitüleri Yayın No Tekel 277 EM/001. İstanbul.

Peksüslü. A ve Gencer. S 2001. Ege Bölgesi Tütünlerinin Kimyasal Özelliklerinin Saptanması. Ege İhracatçı Birlikleri. 2000 Y1lı sonuç Raporu. E.T.A.E. Menemen/İzmir.

Sekin, S., 1987. Tütün Biyokimyası ve Teknolojisi. Ege Üniv. Zir. Fak. Yüksek Lisans Ders Notları. Bornova/İzmir.

Sekin, S., 1979. Tütünde Bazı Analiz Yöntemleri Üzerinde Araştırmalar.Ege Bölgesi Tütünlerinin Kimyasal Bileşimleri ve Fermantaston Sırasında Meydana Gelen Değişmeler. E.Ü.Z.F. Agronomi-Genetik Kürsüsü (Doçentlik Tezi) Bornova/İzmir.

Sekin, S. ve Peksüslü, A., 1995. Ege Tütün Genotip ve Islah Hatlarını Performansları 1993-1995). I. Agronomik Özellikler. Milli Tütün Komitesi Bilimsel Araştırma Alt Komitesi 13. Toplantısında Sunulan Bildiriler ve Toplantı Tutanakları. 25-27 Ekim 1995. Cevizli/İstanbul.

Tso, T.C., 1972. Physiology and Biochemistry of Tobacco Plant. Dowden. Hutchinson and Ross. Inc. Stroudsburg. Pa.

Tuncay, H., S., Sekin, A., Özçam, 1985. Akhisar-Manisa Bölgesinde Tütün Yetiştirilen Toprakların Toprak Özellikleri ve Toprak Özellikleri ile Tütün Kalitesi Arasındaki İlişkiler. Araştırmalar. Doğa Tu. Tar. Or. D.C.10.S.3.

Uz, E., 1997, İki Ege Tütün Çeşidinde Farklı Dikim Zamanları ile Plastik Örtülü Yüksek Tünelde Kurutmanın Verim ve Kalite Üzerine Etkileri. E.Ü. Fen Bilimleri Enstitüsü. (Doktora Tezi). Bornova/İzmir.

Wolf, F.A., 1962, Aromatic or Oriental Tobaccos. Duke University Pres.Durhan. N.C.

Yazan, G., Apti, R., Usturalı, R., Dizdaroğlu, T., Otan, H., 1993. Ege Bölgesi Tütünlerinin Plastik Örtü Altında Kurutulması. Anadolu. J. Of AARI 1 (1993). 73-97. MARA. ETAE Menemen/İzmir. 